\title{
Electrochemical Syntheses of Poly(4,7-benzofuran ethylene) and Poly(4,7-benzothiophene ethylene)
}

\author{
Jonas Gruber, ${ }^{\dagger}$ Rosamaria Wu Chia Li, Adélia M. L. Silva, and Jivaldo R. Matos \\ Instituto de Quimica da Universidade de São Paulo, Caixa Postal 26077-CEP 05599-970, \\ São Paulo-SP-Brazil
}

(Received January 29, 1997)

\begin{abstract}
Poly(4,7-benzofuran ethylene) (PBFE) and poly(4,7-benzothiophene ethylene) (PBTE) were obtained by the cathodic reduction of 4,7-bis(bromomethyl)benzofuran and 4,7-bis(bromomethyl)benzothiophene at a stirred mercury pool cathode. Spectroscopic and thermal analysis data are also presented.

KEY WORDS Poly(p-xylylene) (PPX) / Cathodic Reduction / Electropolymerization / Poly(4,7-

benzofuran ethylene) / Poly(4,7-benzothiophene ethylene) /
\end{abstract}

Poly( $p$-xylylene)s (PPX), are a class of high performance materials used as special coatings for the electronic industry due to their excellent dielectric and insulating properties. ${ }^{1}$ They are usually prepared via pyrolysis of $p$-xylene and of $[2,2]$ paracyclophane. ${ }^{2}$

We have recently synthesised a variety of poly $(p-$ xylylene)s (PPXs) ${ }^{3}$ and poly ( $p$-arylenevinylene)s (PAVs $)^{4}$ by the cathodic reduction of $\alpha, \alpha^{\prime}$-dibromo- $p$-xylenes and $\alpha, \alpha, \alpha^{\prime}, \alpha^{\prime}$-tetrabromo- $p$-xylenes, respectively. Copolymers have been also obtained. The reductions are carried out at a stirred mercury pool cathode and proceed to completion. As shown in Figure 1, the reaction involves the formation of quinodimethane intermediates that polymerize to linear polymers. The insoluble polymers formed precipitate and the soluble fraction in $N, N$ dimethylformamide (DMF) can also be easily separated by the addition of water to the catholite. This nonthermal method offers the possibility of producing a wide range of polymers and copolymers with various substituents that could not survive the pyrolysis involved in the usual route.

In this paper we report the electrosynthesis of two PPX-type polymers (I) and (II), in which heterocyclic pseudoaromatic rings are fused onto the phenylene units (Figure 2). We also report herein some of their spectroscopic data and thermal stability. As far as we know these polymers were never prepared before.

\section{EXPERIMENTAL}

\section{Melting Points}

Melting point data are uncorrected and were measured with an Electrothermal 9100 melting point apparatus or an Dynamic Optics AHT microscope melting point apparatus.

\section{Solvents, Electrolyte, and Reagents}

$N, N$-Dimethylformamide $(D M F) \quad$ For the CV experiments and the preparative electrolyses, commercial DMF (Aldrich GPR) was dried over anhydrous $\mathrm{CuSO}_{4}$ for 2 days and then distilled at $44-45^{\circ} \mathrm{C}(25 \mathrm{mmHg})$ through a $40 \mathrm{~cm}$ vigreux column and stored over freshly baked $4 \AA$ molecular sieves.

\footnotetext{
${ }^{\dagger}$ To whom correspondence should be addressed.
}

Tetraethylammonium Bromide (TEAB) Commercial grade TEAB was baked at $150^{\circ} \mathrm{C}$ overnight before use.

Carbon Tetrachloride Commercial grade $\mathrm{CCl}_{4}$ was heated under reflux over phosphorous pentoxide for 10 hours before distillation. It was stored over freshly baked $4 \AA$ molecular sieves.

$N$-Bromosuccinimide (NBS) Commercial grade NBS was recrystallized from ten times its weight of hot water and dried in a vacuum desiccator over phosphorous pentoxide.

\section{Electrochemical Experiments}

Cyclic voltammetric experiments (CV) were carried out using a USP electronics workshop-constructed triangular wave generator/potentiostat with a PAR RE0074 XY recorder. Controlled potential electrolysis experiments were carried out using a potentiostat with an electronic charge integrator constructed in our laboratory. 5,6

Conventional glass cells were used, as described further on.

\section{Spectroscopic Studies}

${ }^{1} \mathrm{H}$ NMR FT spectra $(200 \mathrm{MHz})$ were recorded on a Bruker AC-200 spectrometer using deuteriated chloroform/TMS as solvent/reference.

FT-IR spectra were recorded as a $\mathrm{KBr}$ disc, on a Perkin-Elmer 1750 series grating. Only major or im-

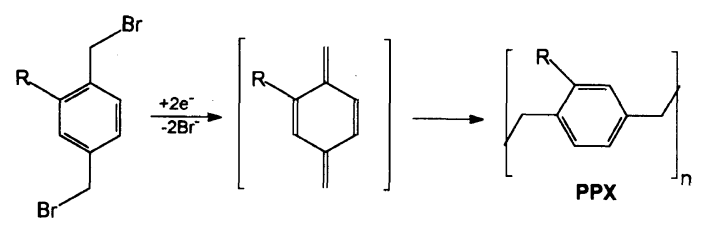

$\mathrm{R}=\mathrm{H}, \mathrm{OMe}, \mathrm{CO}_{2} \mathrm{Me}, \mathrm{OCOMe}$

Figure 1. Electrochemical route to PPXs.

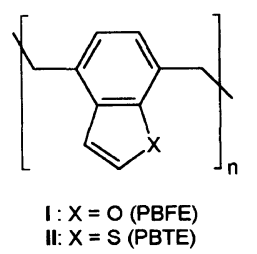

Figure 2. Chemical structures of PBFE and PBTE. 
portant absorptions are given.

\section{Thermal Analyses}

Thermogravimetric (TG) and derivative thermogravimetric (DTG) curves were obtained with a thermobalance model TGA50 (Shimadzu), using platinum crucibles with $c a .3 \mathrm{mg}$ of the sample, under dynamic air atmosphere $\left(50 \mathrm{~mL} \mathrm{~min}^{-1}\right)$ and heating rate of $10^{\circ} \mathrm{C} \mathrm{min}^{-1}$.

Differential scanning calorimetry (DSC) curves were obtained with DSC50 (Shimadzu) cell using aluminum crucibles with ca. $1.5 \mathrm{mg}$ of the sample, and dynamic nitrogen atmosphere $\left(50 \mathrm{~mL} \mathrm{~min}^{-1}\right)$ and heating rates of $10^{\circ} \mathrm{Cmin}^{-1}$.

\section{Elemental Analyses}

Elemental analyses were carried out on a Perkin Elmer Elemental Analyzer $2400 \mathrm{CHN}$.

\section{Starting Materials}

Compounds (III) and (IV) were obtained following methods described in the literature. ${ }^{7}$

Preparation of 4,7-Bis(bromomethyl)benzofuran $(V)$ 4,7-Dimethylbenzofuran (III) (1.00 g; $6.85 \mathrm{mmols})$, NBS $(3.05 \mathrm{~g} ; 17.1 \mathrm{mmol})$ and dibenzoyl peroxide $(12.3 \mathrm{mg})$ were added to dry carbon tetrachloride $(20 \mathrm{~mL})$ and heated to reflux for 6 hours under VIS illumination ( $300 \mathrm{~W}$ halogen bulb), then cooled to room temperature. The insoluble succinimide was filtered off then washed with chloroform. The combined filtrate was shaken with aqueous sodium chloride and then with water. After drying over anhydrous magnesium sulphate and solvent evaporation, the solid was recrystallized $\left(\mathrm{CHCl}_{3} /\right.$ hexane $)$ to give yellow crystals, yield $0.472 \mathrm{~g}(1.55 \mathrm{mmol} ; 23 \%)$. mp $150-154^{\circ} \mathrm{C}\left(\right.$ lit $\left.^{7} 152-154^{\circ} \mathrm{C}\right) . \delta_{\mathrm{H}}: 4.71(2 \mathrm{H}, \mathrm{s}$, $\left.\mathrm{CH}_{2} \mathrm{Br}\right) ; 4.78\left(2 \mathrm{H}, \mathrm{s}, \mathrm{CH}_{2} \mathrm{Br}\right) ; 6.98(1 \mathrm{H}, \mathrm{d}, \beta-\mathrm{CH}$, $J=2.0 \mathrm{~Hz}) ; 7.20-7.30(2 \mathrm{H}, \mathrm{m}, 5,6-\mathrm{Ar}-\mathrm{H}) ; 7.77(1 \mathrm{H}, \mathrm{d}$, $\alpha-\mathrm{CH}, J=2.0 \mathrm{~Hz}) . \mathrm{CV}:-1.49 \mathrm{~V}$ vs. $\mathrm{Ag} / \mathrm{AgBr}$.

Preparation of 4,7-Bis(bromomethyl)benzothiophene (VI) 4,7-Dimethylbenzothiophene (IV) $(0.470 \mathrm{~g} ; 2.90$ mmol), NBS (1.30 g; $7.31 \mathrm{mmol}$ ) and dibenzoyl peroxide $(5.0 \mathrm{mg})$ were added to dry carbon tetrachloride $(9 \mathrm{~mL})$ and were treated as above and the obtained solid was recrystallized (petroleum ether $30-50^{\circ} \mathrm{C}$ ) to give yellow crystals, yield $0.582 \mathrm{~g}(1.81 \mathrm{mmol} ; 63 \%)$. mp $168-172^{\circ} \mathrm{C}$ (lit $\left.{ }^{7} 168-169^{\circ} \mathrm{C}\right) . \delta_{\mathrm{H}}: 4.76\left(2 \mathrm{H}, \mathrm{s}, \mathrm{CH}_{2} \mathrm{Br}\right) ; 4.82(2 \mathrm{H}, \mathrm{s}$, $\left.\mathrm{CH}_{2} \mathrm{Br}\right) ; 7.36(2 \mathrm{H}, \mathrm{s}, 5,6-\mathrm{Ar}-\mathrm{H}) ; 7.62(1 \mathrm{H}, \mathrm{s}, \alpha-$, or $\beta-\mathrm{CH})$; $7.63(1 \mathrm{H}, \mathrm{s}, \alpha-$, or $\beta-\mathrm{CH}) . \mathrm{CV}:-1.85 \mathrm{~V}$ vs. $\mathrm{Ag} / \mathrm{AgBr}$.

\section{Electrolyses}

Controlled Potential Electrolysis of 4,7-Bis(bromomethyl)benzofuran ( $V$ ) Compound (V) (0.450 g; 1.48 mmol) was electrolysed at a mercury pool cathode in $\mathrm{Et}_{4} \mathrm{NBr}\left(0.1 \mathrm{~mol}^{-1}\right)-\mathrm{DMF}$ solution $(50 \mathrm{~mL})$ at $-1.49 \mathrm{~V}$ (vs. $\mathrm{Ag} / \mathrm{AgBr}$ ) in a divided cell. A yellow precipitate formed during electrolysis. After ca. $2.2 \mathrm{~F} \mathrm{~mol}^{-1}$ had passed, the cell current dropped close to the background value. The precipitate was filtered and washed several times with water to remove $\mathrm{DMF}$ and $\mathrm{Et}_{4} \mathrm{NBr}$, and dried in vacuo. On adding water to the filtrate, another crop of polymer was obtained (soluble fraction), which was also washed and dried. Yield: $183 \mathrm{mg}(1.27 \mathrm{mmol} ; 86 \%)$ of insoluble fraction and $14.5 \mathrm{mg}(0.101 \mathrm{mmol} ; 7 \%)$ of soluble fraction which gave $\delta_{\mathrm{H}}: 2.86-2.98(4 \mathrm{H}$, br m,
$\left.-\mathrm{CH}_{2}-\mathrm{CH}_{2}-\right) ; 6.57(1 \mathrm{H}$, br s, $\beta-\mathrm{CH}) ; 6.90-7.10(2 \mathrm{H}, \mathrm{m}$, ArH5 and ArH6); 7.51 (1H, brs, $\alpha$-CH). FT-IR: 3023 $\left(v_{\text {arom. }} \mathrm{C}-\mathrm{H}\right) ; 2924$ and $2854\left(v_{\text {sat. }} \mathrm{C}-\mathrm{H}\right) ; 1625,1591,1542$, and 1499 (benzene ring); 928, 874, and $832(\gamma-\mathrm{C}-\mathrm{H}$ or $\beta$-ring).

Controlled Potential Electrolysis of 4,7-Bis(bromomethyl)benzothiophene (VI) Compound (VI) (0.380 g; $1.19 \mathrm{mmol})$ was electrolysed as above at $-1.85 \mathrm{~V}$. Yield: $62 \mathrm{mg}(0.39 \mathrm{mmol} ; 33 \%)$ of insoluble fraction and $40 \mathrm{mg}$ $(0.25 \mathrm{mmol} ; 21 \%)$ of soluble fraction. The soluble fraction gave $\delta_{\mathrm{H}}: 2.57-2.62\left(4 \mathrm{H}\right.$, br m, $\left.-\mathrm{CH}_{2}-\mathrm{CH}_{2}-\right) ; 7.25-$ $7.30\left(4 \mathrm{H}\right.$, br m, H1, H2, H5, and H6). FT-IR: 3025 ( $v_{\text {arom }}$ $\mathrm{C}-\mathrm{H}) ; 2916$ and $2854\left(v_{\text {sat. }}\right.$ C--H); 1636 and 1566 (benzene ring); 929, 803, and $764(\gamma-\mathrm{C}-\mathrm{H}$ or $\beta$-ring).

\section{RESULTS AND DISCUSSION}

\section{Preparation of Precursors}

4,7-Dimethylbezofuran (III) and 4,7-dimethylbenzothiophene (IV) were obtained from 2,5-dimethylphenol and 2,5-dimethylthiophenol, respectively, according to procedures described by Sarker et al., ${ }^{7}$ and the novel dibromo-compounds (V) and (VI) by the treatment of (III) and (IV) with an excess of $N$-bromosuccinimide (NBS), in the presence of visible light and peroxide (Figure 3). ${ }^{1} \mathrm{H}$ NMR, IR, and elemental analyses agreed with their expected structures.

\section{Cyclic Voltammetry}

Single-sweep voltammetry of compounds (V) and (VI) at a mercury bead cathode in DMF-TEAB $(0.1$ $\mathrm{mol} \mathrm{L}^{-1}$ ) at $0.40 \mathrm{~V} \mathrm{~s}^{-1}$ revealed irreversible reduction peaks (Figure 4$)$ and the most negative ones $\left(E_{\mathrm{red}}\right.$ in Table I) could be used successfully for the reduction potentials of controlled potential electrolysis.

\section{Controlled Potential Electrolyses}

These were carried out on an $0.5 \mathrm{~g}$ scale in a con-

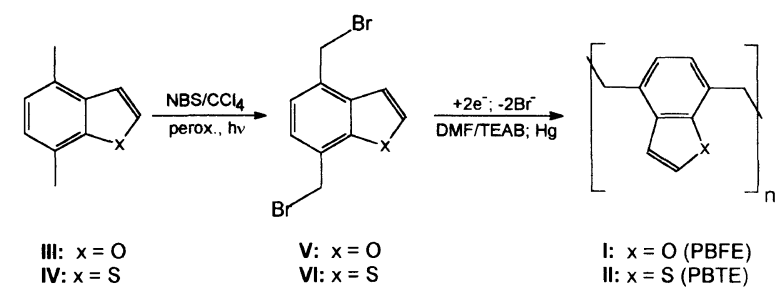

Figure 3. Formation of polymers (I) and (II).

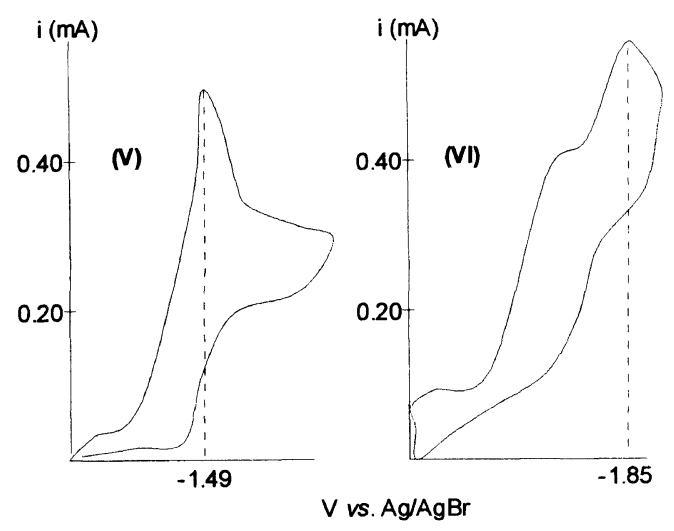

Figure 4. Cyclovoltammograms of compounds (V) and (VI). 
Table I. Some experimental data for precursors (V, VI) and polymers (I, II)

\begin{tabular}{|c|c|c|c|c|}
\hline \multirow{2}{*}{ Precursor } & \multirow{2}{*}{ Polymer } & $-E_{\mathrm{red}}$ & \multirow{2}{*}{ Yield $/ \%$} & \multirow{2}{*}{$\begin{array}{c}\begin{array}{c}\text { Soluble } \\
\text { fraction }\end{array} \\
\%\end{array}$} \\
\hline & & V & & \\
\hline $\mathrm{V}$ & I & 1.49 & 93 & 7 \\
\hline VI & II & 1.85 & 54 & 21 \\
\hline
\end{tabular}
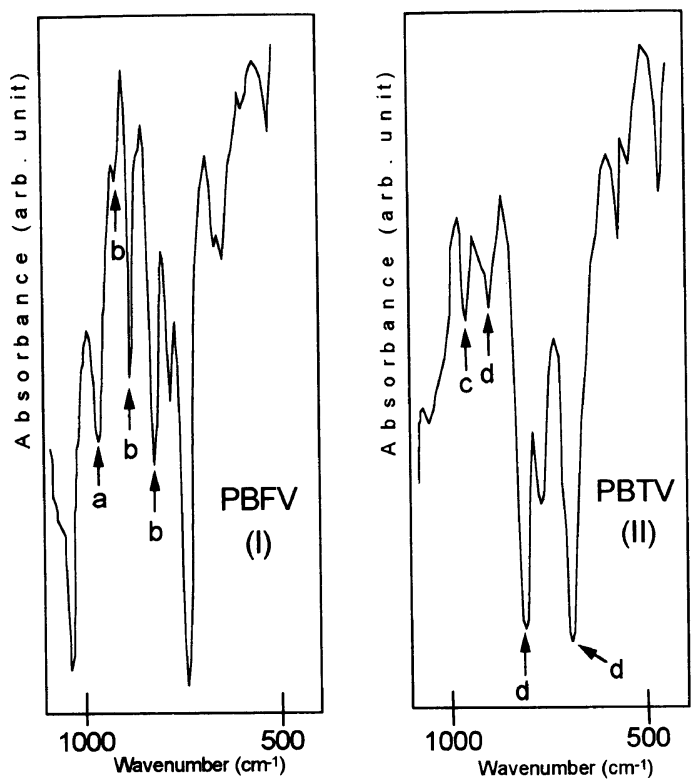

Figure 5. IR spectra of PBFE and PBTE: (a)-(f) $\gamma-\mathrm{C}-\mathrm{H}$ or $\beta$-ring modes.

ventional cell equipped with a magnetically stirred mercury pool cathode, a $\mathrm{Ag} / \mathrm{AgBr}$ reference electrode, a graphite anode and a microporous divider. The solvent was DMF containing $0.1 \mathrm{~mol} \mathrm{~L}^{-1} \mathrm{Et}_{4} \mathrm{NBr}$ as supporting electrolyte. The cathode compartment was continually flushed with a slow stream of dry nitrogen.

The dibrominated precursors (V) and (VI) were converted to the corresponding polymers (I) and (II) (Figure 3 ) and the reactions were complete after the passages of $\sim 2 \mathrm{~F} \mathrm{~mol}^{-1}$, at which point the current had fallen to the background level. Part of the polymers precipitated during electrolysis and the residual was obtained from the DMF filtrate after dilution with water.

In both cases good yields of the polymers were obtained, with a significant proportion of soluble material (Table I). The insoluble fractions precipitated as fibrous yellow solids.

\section{Spectroscopy Studies}

The methodology used to establish the key structural features of these electrosynthesized polymers was essentially that used for the analogous PPXs and PPVs and it has been fully described. ${ }^{3,4}$ Spectroscopic data is given in the Experimental section.

Important observations include the IR absorptions at $928,874,832 \mathrm{~cm}^{-1}$ (polymer I) and $929,803,764 \mathrm{~cm}^{-1}$ (polymer II) characteristic for $\gamma$ - $\mathrm{CH}$ or $\beta$-ring bands of furan and thiophene derivatives (Figure 5). For soluble fractions it was possible to obtain ${ }^{1} \mathrm{H}$ NMR spectra and, although the peaks are somewhat broadened, the

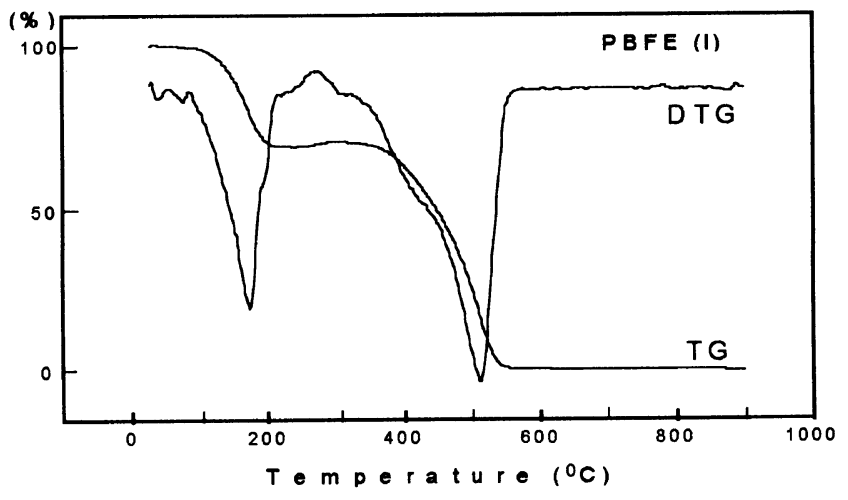

Figure 6. TG and DTG curves for PBFE (I) in dynamic air atmosphere and heating rate of $10^{\circ} \mathrm{C} \mathrm{min}^{-1}$.

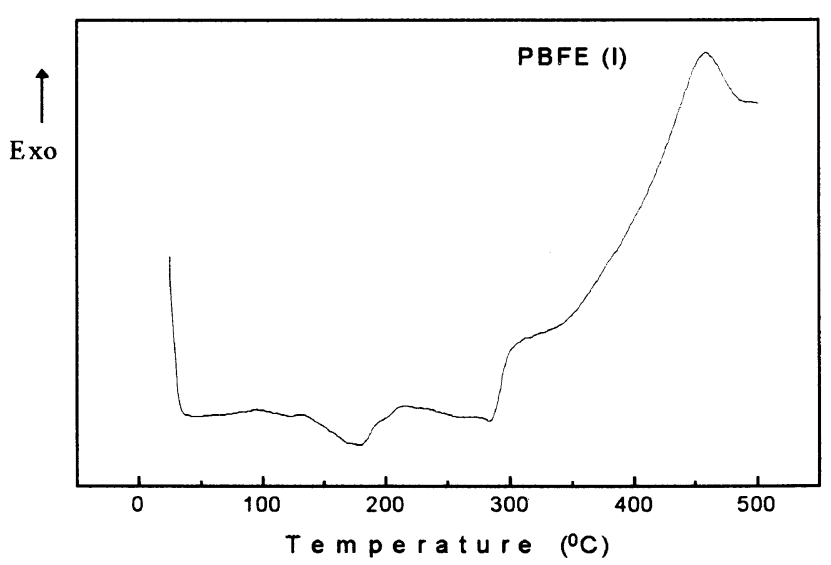

Figure 7. DSC curve for PBFE (I) in dynamic nitrogen atmosphere and heating rate of $10^{\circ} \mathrm{Cmin}^{-1}$.

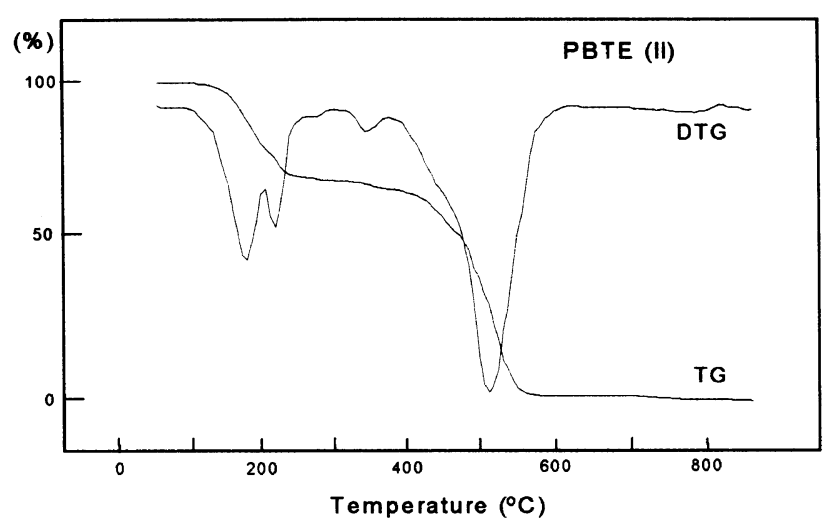

Figure 8. TG and DTG curves for PBTE (II) in dynamic air atmosphere and heating rate of $10^{\circ} \mathrm{C} \mathrm{min}^{-1}$.

chemical shifts and integrations are as expected for these oligomers.

\section{Thermal Analyses}

Both polymers (insoluble fractions) were examined by differential scanning calorimetry (DSC) and thermogravimetry (TG)/derivative thermogravimetry (DTG). TG/DTG and DSC curves are shown in Figures 6-9 and the main observations are as follows: (i) polymers (I) and (II) show similar thermal behavior in their TG/DTG curves. Nevertheless, they show differences in the DSC curves. There is a weight loss of about $30 \%$ that occurs under $200^{\circ} \mathrm{C}$ which is endothermic for polymer (I) and involves probably endothermic and 


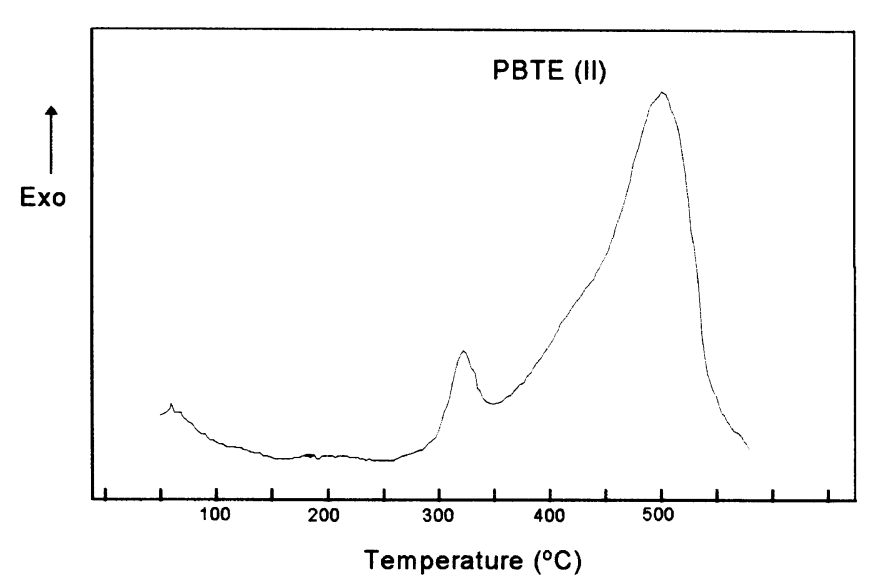

Figure 9. DSC curve for PBTE (II) in dynamic nitrogen atmosphere and heating rate of $10^{\circ} \mathrm{Cmin}^{-1}$.

exothermic steps that compensate energetically for polymer (II), since no enthalpy changes can bee seen under $\sim 270^{\circ} \mathrm{C}$. These weight losses are probably due to vaporization of small oligomers such as monomer, dimer, and trimer, since samples heated for 1 hour at $200^{\circ} \mathrm{C}$ did not show any changes in their IR spectra. The strange thermal behavior observed for polymer (II) may arise from further oxidation reactions of the lost oligomers. (ii) the remained weight is gradually lost between 380 and $550^{\circ} \mathrm{C}$ in an exothermic process, and (iii) no glass transition or melting points could be observed.

\section{CONCLUSIONS}

The cathodic elimination reaction of 4,7-bis(bromo- methyl) derivatives of benzofuran and benzothiophene yields the corresponding polymers, PBFE and PBTE, respectively, in good yields. At the stirred mercury pool cathode reaction proceeds to completion because any insulating film is continuously broken up.

The electrochemical route described in this paper has the advantage of its inherent smooth conditions.

Acknowledgements. The authors are grateful to the Fundação de Amparo à Pesquisa do Estado de São Paulo (FAPESP), to the Conselho Nacional de Desenvolvimento Científico e Tecnológico (CNPq) and to Sinc do Brasil for their financial supports.

\section{REFERENCES}

1. S. M. Lee, "Kirk-Othmer Encyclopedia of Chemical Technology," Vol. 24, 3rd ed, John Wiley \& Sons, New York, N.Y., 1983, pp. $744-771$.

2. M. Szwarc, Nature (London), 160, 403 (1947); US Patent 3342 754 (1967).

3. J. H. P. Utley, Y. Gao, J. Gruber, and R. Lines, J. Mater. Chem., 5, 1297 (1995).

4. J. H. P. Utley, Y. Gao, J. Gruber, Y. Zhang, and A. Munoz-Escalona, J. Mater. Chem., 5, 1837 (1995).

5. J. Gruber, V. L. Pardini, and H. Viertler, Química Nova, 15, 83 (1992).

6. J. Gruber, V. L. Pardini, H. Viertler, and I. Gruber, Anal. Instrum., 20, 155 (1992).

7. A. Sarker, P. M. Lahti, and F. E. Karasz, J. Polym. Sci., Part A, Polym. Chem., 32, 65 (1994). 